Vol. 27, No. 2 Agustus (2020), 172- 182

P-ISSN : 0854-641X \& E-ISSN : 2407-7607, Diterbitkan Universitas Tadulako

\title{
STUDI KOMPARATIF PROSES BISNIS USAHA JIGANA COFFEE SHOP DAN KEDAI KOPI INSPIRASI CIBINONG, KABUPATEN BOGOR
}

\section{A Comparative Study of Business Proccess between Jigana Coffee Shop and Kedai Kopi Inspirasi in Cibinong of Bogor Regency}

\author{
Alvi Nurin Deaniera' ${ }^{1)}$, Elly Rasmikayati' ${ }^{2)}$, Bobby Rachmat Saefudin ${ }^{3)}$, Dika Supyandi ${ }^{4}$, \\ Yayat Sukayat ${ }^{5}$ \\ ${ }^{1,2,4,5)}$ Program Studi Agribisnis, Fakultas Pertanian, Universitas Padjadjaran \\ ${ }^{3)}$ Program Studi Agribisnis, Fakultas Pertanian, Ma'soem University \\ 1email: alvinurindeaniera@gmail.com
}

Submit: 8 Juli 2020, Revised: 6 Agustus 2020, Accepted: Agustus 2020

\begin{abstract}
Coffee shops have become a part of human lifestyle and are popular among coffee consumers which make them a promising business prospect. The spread of the coffee shops generates a tight business competition, resulting in a sales fluctuation from the uncompetitive coffee shops. The objective of this research was to describe consumer characteristics, business process, potential, and obstacles experienced by Jigana Coffee Shop and Kedai Kopi Inspirasi. The method used in this research was a survey method with tools of descriptive statistics. The size of the sample in this research was 27 persons at Jigana Coffee Shop and 45 persons at Kedai Kopi Inspirasi. The result of this research showed that the consumers of Jigana Coffee Shop and Kedai Kopi Inspirasi were dominated by productive men aged 20-30 years old with average salary IDR 1,000,000-Rp 5,000,000. From the consumer behaviour side, most consumers of both coffee shops were more interested in the coffee shop which provide a good taste of coffee and had a comfortable environment. The business process of both Jigana Coffee Shop and Kedai Kopi Inspirasi were relatively similar. The business potential and obstacles of Jigana Coffee Shop and Kedai Kopi Inspirasi were product variables, location, facilities, the completeness of the equipment, and human resources.
\end{abstract}

Keywords: Business Process and Coffee Shop.

\begin{abstract}
ABSTRAK
Kedai kopi menjadi bagian dari gaya hidup serta banyak digemari oleh konsumen kopi sehingga menjadi prospek usaha yang menjanjikan. Menjamurnya kedai kopi ini menyebabkan ketatnya persaingan bisnis sehingga terjadinya fluktuasi penjualan bagi kedai kopi yang kurang dapat bersaing. Penelitian ini bertujuan untuk mendeskripsikan karakteristik konsumen, proses bisnis, serta potensi dan kendala yang dialami Jigana Coffee Shop dan Kedai Kopi Inspirasi. Metode yang digunakan dalam penelitian ini adalah metode survey dengan alat analisis statistic deskriptif. Jumlah sampel pada penelitian ini ada 27 orang pada Jigana Coffee Shop dan 45 orang pada Kedai Kopi Inspirasi. Hasil penelitian menunjukkan bahwa karakteristik konsumen di Jigana Coffee Shop dan Kedai Kopi Inspirasi didominasi oleh laki-laki dan pada usia produktif, yaitu dari 20-30 tahun dengan penghasilan rata-rata Rp 1.000.000 - Rp 5.000.000. Dari segi perilaku konsumen, sebagian besar
\end{abstract}


konsumen kedua kedai kopi tersebut lebih tertarik dengan kedai kopi yang rasanya enak/nikmat dan suasana yang nyaman. Proses bisnis yang ada di Jigana Coffee Shop dan Kedai Kopi Inspirasi ini relatif sama. Potensi dan kendala dari Jigana Coffee Shop dan Kedai Kopi Inspirasi ada pada variable produk, lokasi, fasilitas, kelengkapan alat, dan sumberdaya manusia.

Kata-Kata Kunci: Studi Komparatif; Karakteristik; Proses Bisnis dan Kedai Kopi

\section{PENDAHULUAN}

Kopi merupakan salah satu komoditas perkebunan yang memiliki peran penting dalam perekenomian Indonesia (Widyotomo, 2013). Peran tanaman kopi dalam perekonomian Indonesia menurut Afriyanti dan Rasmikayati (2018) antara lain menjadi sumber penghasilan rakyat serta meningkatkan devisa negara melalui ekspor biji mentah maupun olahan dari biji kopi. Indonesia merupakan salah satu produsen kopi terbaik dengan ciri khas komoditas daerah yang berbeda-beda, seperti Java Preanger, Aceh Gayo, Bali Kintamani, Toraja, Papua Wamena dan lainnya (FAO, 2015). Sebagai penghasil kopi terbaik, tingkat konsumsi kopi di Indonesia juga mengalami peningkatan setiap tahunnya. Hal ini dapat dilihat pada Gambar 1. ICO (2018) menyatakan bahwa konsumsi kopi di Indonesia telah meningkat dalam beberapa tahun terakhir. Peningkatan konsumsi kopi ini menjelaskan bahwa adanya minat masyarakat terhadap produk kopi.

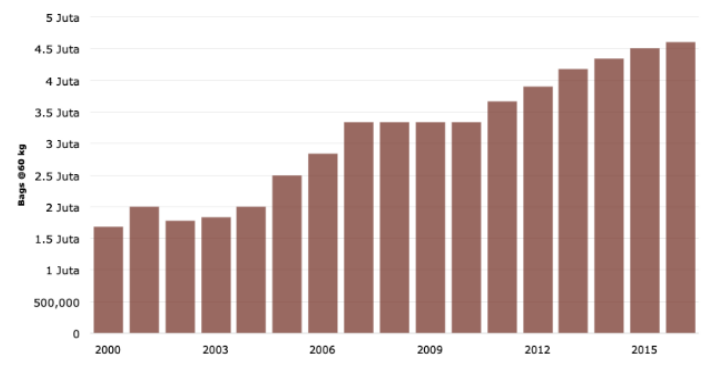

Gambar 1. Konsumsi Kopi di Indonesia Tahun 20002016

Sumber: ICO (2018)

Seiring dengan meningkatnya minat dan permintaan masyarakat Indonesia terhadap produk kopi, jumlah kedai kopi yang ada di Indonesia juga mengalami peningkatan yang signifikan (Rasmikayati dkk, 2017). Merek kedai kopi lokal yang tidak kalah bersaing dengan merek internasional seperti 173
Starbucks, Coffee Toffee, The Coffee Bean \& Tea Leaf dan lainnya inilah yang juga menyebabkan tren kedai kopi di Indonesia meningkat setiap tahunnya (Jeon et al., 2019; Neilson et al., 2018; Wang et al., 2019, p.).

Pertumbuhan jumlah kedai kopi ini terjadi di berbagai daerah, salah satunya di Kecamatan Cibinong. Hal ini dapat dilihat dari Gambar 2 yang menjelaskan bahwa adanya peningkatan jumlah kedai kopi di Cibinong setiap tahunnya. Hal yang menarik adalah kedai-kedai ini didirikan dan dikelola oleh anak-anak muda yang tertarik dalam mengembangkan potensi kopi. Merujuk pada Rasmikayati dkk (2017) dan Pardian (2017), seiring perkembangan pasar komoditas pertanian di Indonesia memicu peningkatan minat para pengusaha muda untuk mengembangkan usaha agribisnis, dalam hal ini usaha kedai kopi. Tren pertumbuhan kedai kopi yang sejenis maupun berbeda di Cibinong ini juga menyebabkan adanya tingkat persaingan yang semakin ketat antar kedai kopi satu dengan yang lainnya sehingga berpengaruh pada jumlah penjualan suatu kedai kopi (Filimonau et al., 2019; Song et al., 2019; van Ooyen-Houben et al., 2016).

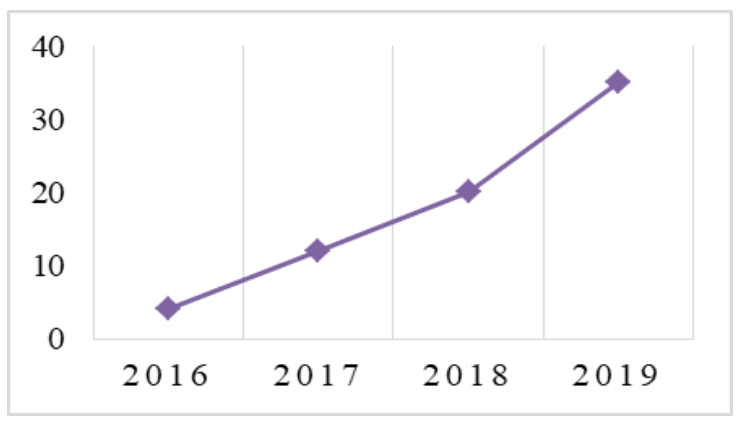

Gambar 2. Tren Pertumbuhan Kedai Kopi di Cibinong Tahun 2016-2019

Sumber: Hasil Observasi Peneliti (2020)

Beberapa kedai kopi yang ada di Cibinong diantaranya Jigana Coffee Shop 
dan Kedai Kopi Inspirasi. Kedua kedai kopi ini dapat dikatakan berada dalam lingkungan yang kompetitif. Hal ini terlihat dari beragamnya kedai kopi yang ada disekitar lokasi yang juga menawarkan berbagai konsep dalam rangka merebut dan mempertahankan pasar. Menjamurnya kedai kopi yang sejenis maupun berbeda itu berpengaruh terhadap jumlah kunjungan konsumen sehingga menyebabkan fluktuasi penjualan di kedai kopi itu sendiri (Anderzén et al., 2020; Han et al., 2018; Park et al., 2017).

Penentuan lokasi tempat untuk setiap bisnis merupakan suatu tugas penting bagi pemasar. Keputusan yang salah pun juga dapat mengakibatkan kegagalan sebelum bisnis dimulai. Menurut Tjiptono (2004), faktor-faktor yang memengaruhi atau perlu ditimbangkan dalam pemilihan lokasi usaha diantaranya memiliki akses yang mudah dijangkau, visibilitas yang jelas, lalu lintas dimana banyak orang lalu lalang sehingga memberikan peluang besar, tempat parkir yang luas dan aman, tersedianya tempat yang cukup luas untuk perluasan usaha, lingkungan sekitar yang mendukung jasa yang ditawarkan, dan lokasi pesaing (Amir dkk, 2017). Namun, pada kenyataannya lokasi dari Jigana Coffee Shop yang dapat dikatakan strategis ini justru mengalami penjualan yang menurun, sedangkan lokasi dari Kedai Kopi Inspirasi yang dapat dikatakan kurang strategis ini lebih ramai pengunjung dan penjualannya meningkat.

Adanya situasi dan kondisi persaingan yang semakin ketat, pemilik atau pengelola kedai kopi tidak saja harus mampu menjual produk dan jasanya, tetapi juga harus memiliki kemampuan untuk mengerti dan memahami selera konsumen (Ballco et al., 2020; Khan and Lee, 2020; Spiller, 2012). Dengan demikian, peneliti ingin mengetahui tujuan konsumen yang datang ke Jigana Coffee Shop dan Kedai Kopi Inspirasi. Disamping itu, peneliti juga ingin mengetahui proses bisnis serta potensi dan kendala yang ada di Jigana Coffee Shop dan Kedai Kopi Inspirasi dalam rangka memenuhi keinginan konsumen.

\section{METODE PENELITIAN}

Penelitian ini dilaksanakan bulan Desember - Januari 2018 di Jigana Coffee Shop dan Kedai Kopi Inspirasi, Cibinong.
Desain penelitian ini adalah kuantitatif dengan teknik penelitian yang digunakan oleh penulis adalah metode survey. Pengumpulan data dilakukan dengan melakukan wawancara, kuesioner (angket), dan studi pustaka. Rancangan alat analisis data yang digunakan adalah analisis statistik deskriptif.

Pengambilan sampel yang digunakan dalam penelitian ini adalah systematic sampling. Penentuan jumlah sampel yang diteliti oleh peneliti dilakukan berdasarkan perhitungan rumus Cochran, yaitu:

$$
n=\frac{z^{2} p q}{e^{2}}
$$

\section{Keterangan:}

$n \quad=$ Jumlah sampel yang diperlukan

$\mathrm{z}=$ Harga dalam kurve normal untuk simpangan 5\%, dengan nilai 1,96

$\mathrm{p} \quad=$ Peluang benar $50 \%(0,5)$

$\mathrm{q}=$ Peluang salah $50 \%(0,5)$

e = Tingkat kesalahan sampel, yaitu $15 \%$ atau 0,15

Berdasarkan rumus diatas, diperoleh jumlah sampel (n) sebagai berikut.

$$
\begin{aligned}
& n=\frac{z^{2} p q}{e^{2}} \\
& n=\frac{(1,96)^{2}(0,5)(0,5)}{(0,15)^{2}} \\
& n=\frac{0,9604}{0,04}=42,6 \approx 43 \text { (dibulatkan) }
\end{aligned}
$$

Untuk menghindari kesalahan saat pengambilan data primer, peneliti merasa bahwa sampel sebaiknya diambil melebihi dari standar perhitungan. Maka dari itu peneliti memutuskan untuk menetapkan jumlah sampel sebanyak 45 responden untuk setiap kedai kopi. Responden penelitian ini yaitu konsumen dari Jigana Coffee Shop dan Kedai Kopi Inspirasi. Pada kenyataannya, konsumen kopi Jigana Coffee Shop yang dapat mengisi kuesioner tersebut hanya 27 orang sehingga jumlah tersebut tidak sesuai dengan ukuran sampel yang ditentukan sebelumnya. Maka, total jumlah sampel yang ada di dalam penelitian ini adalah 72 responden, yaitu 27 responden untuk Jigana Coffee Shop dan 45 responden untuk Kedai Kopi Inspirasi. 


\section{HASIL DAN PEMBAHASAN}

\section{Gambaran Umum Tempat Penelitian Jigana Coffee Shop.}

Jigana Coffee Shop terletak di Jl. KSR Dadi Kusmayadi, Desa Tengah, Ruko Perumahan Cibinong Griya Asri, Kecamatan Cibinong, Kabupaten Bogor, Jawa Barat. Lokasi tersebut dinilai cukup strategis karena berada di jalan raya alternatif Cibinong-Bogor-Depok. Posisi Jigana Coffee Shop ini berada di posisi kiri dari arah Jalan Raya Tegar Beriman, Cibinong. Posisi tersebut memudahkan pengunjung yang membawa kendaraan untuk menepi karena merupakan jalur lambat. Tempat lokasi dari Jigana Coffee Shop ini berbentuk ruko dua lantai dan menyediakan lahan parkir. Namun, plang banner dari tulisan Jigana Coffee Shop ini belum terpampang jelas dari jalan raya sehingga kurang memudahkan masyarakat untuk mengetahui lokasi dari kedai kopi ini.

\section{Kedai Kopi Inspirasi.}

Kedai Kopi Inspirasi terletak di Jl. Haji Minggu No. 29, Desa Tengah, Kecamatan Cibinong, Kabupaten Bogor, Jawa Barat. Lokasi Kedai Kopi Inspirasi ini dinilai kurang strategis karena berada di dalam gang, tidak berada di jalan raya utama. Posisi Kedai Kopi Inspirasi ini berada di posisi kiri dari gang masuk melalui Jalan Raya Tegar Beriman, Cibinong. Tempat lokasi Kedai Kopi Inspirasi ini ber-design outdoor dengan menggunakan kebun jati sebagai keunikan dari kedai kopi ini. Selain itu, kedai kopi ini menyediakan lahan parkir yang cukup, namun masih kurang karena pengunjung yang datang pun ramai. Plang tulisan Kedai Kopi Inspirasi ini juga tidak terpampang jelas didepan gang sehinggan kurang memudahkan masyarakat untuk mengetahui lokasi dari kedai kopi ini.

\section{Karakteristik Konsumen.}

Sebagian besar konsumen Jigana Coffee Shop dan Kedai Kopi Inspirasi berjenis kelamin laki-laki. Lebih banyaknya konsumen laki-laki yang membeli kopi di 175
Jigana Coffee Shop dan Kedai Kopi Inspirasi ini sesuai dengan penelitian dari Ni'amullah, Irdiana, \& Irawan (2018) bahwa minum kopi biasanya didominasi oleh kaum pria. Kemudian, konsumen yang berkunjung ke Jigana Coffee Shop dan Kedai Kopi Inspirasi didominasi oleh konsumen yang berusia antara 20-30 tahun.

Konsumen yang datang ke Jigana Coffee Shop sebagian besar berpendidikan terakhis Sarjana/S1, berbeda halnya dengan konsumen Kedai Kopi Inspirasi yang sebagian besar berpendidikan terakhir SMA (sedang kuliah). Mayoritas responden yang memiliki tingkat pendidikan SMA ini sesuai dengan hasil dari penelitian Afriyanti dan Rasmikayati (2018) bahwa konsumen yang datang ke kedai kopi didominasi oleh konsumen yang berstatus sebagai pelajar/mahasiswa/i, khususnya responden yang tingkat pendidikan terakhirnya SMA, namun sedang kuliah.

Konsumen yang datang ke Jigana Coffee Shop sebagian besar berstatus pegawai swasta. Berbeda halnya dengan Kedai Kopi Inspirasi dimana sebagian besar konsumen yang datang berstatus pelajar/mahasiswa/i. Hal ini dikarenakan Kedai Kopi Inspirasi ini tergolong nyaman dan santai untuk sekedar nongkrong serta menghabiskan waktu berdiskusi bersama teman-teman.

Mayoritas responden Jigana Coffee Shop dan Kedai Kopi Inspirasi dengan pendapatan perbulan antara Rp 1.000.000 Rp 5.000.000 merupakan responden yang paling sering berkunjung ke kedai kopi, sehingga sesuai dengan hasil penelitian Gerry et al., (2019) bahwa jumlah responden terbanyak ada pada pendapatan Rp 3.000.000 Rp 5.000.000. Selanjutnya, domisili konsumen yang datang ke Jigana Coffee Shop dan Kedai Kopi Inspirasi mayoritas adalah berasal dari dalam Cibinong.

Jigana Coffee Shop dan Kedai Kopi Inspirasi merupakan salah satu usaha yang bergerak dibidang agribisnis dengan komoditas utama yang diusahakan adalah kopi. Kedua kedai kopi ini melakukan aktifitas bisnis kopi di tingkat hilir. Proses perencanaan didirikannya Jigana Coffee Shop ini berlangsung 
selama empat bulan, yaitu dari bulan Desember 2018 hingga April 2019. Sedangkan, proses perencanaan didirikannya Kedai Kopi Inspirasi ini berlangsung selama lima bulan, dari September 2016 hingga Februari 2017.

Sumber bahan baku yaitu bagaimana pelaku usaha atau pemilik memperoleh bahan baku produknya. Jigana Coffee
Shop dan Kedai Kopi Inspirasi merupakan kedai kopi yang menyajikan kopi nusantara yang berkualitas. Kedua kedai kopi ini memperoleh sumber bahan bakunya dari berbagai supplier. Jigana Coffee Shop memperoleh bahan baku dari 3 supplier. Sedangkan, Kedai Kopi Inspirasi memperoleh bahan bakunya juga dari 3 supplier.

\section{Deskripsi Proses Bisnis}

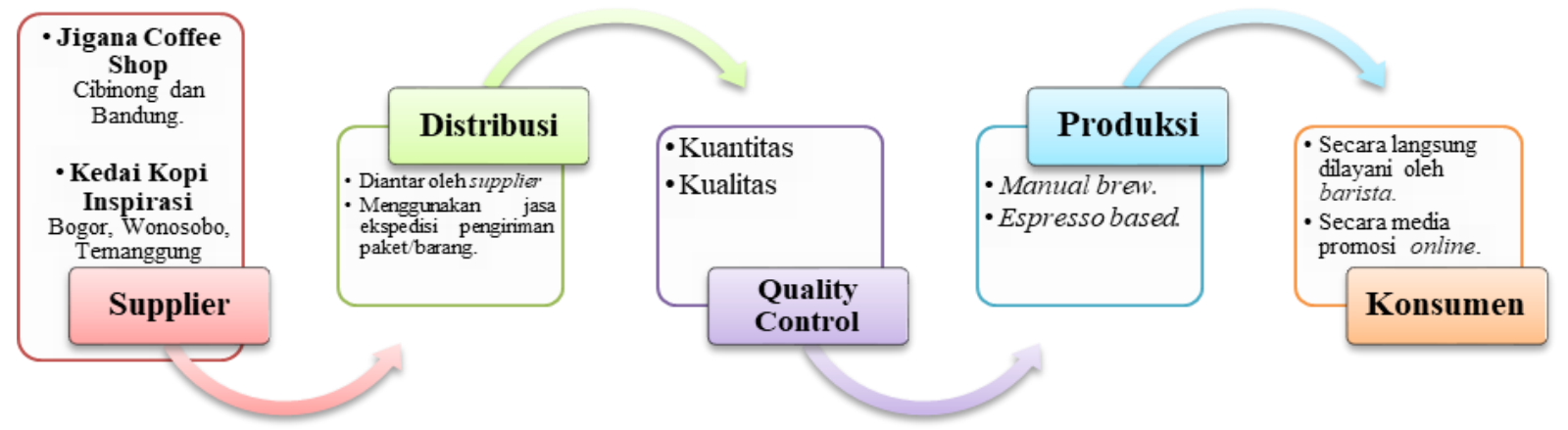

Gambar 3. Alur Proses Bisnis Jigana Coffee Shop dan Kedai Kopi Inspirasi

Tabel 1. Perbandingan Sumber Bahan Baku Kopi

\begin{tabular}{|c|c|c|}
\hline \multirow{2}{*}{ No } & \multicolumn{2}{|c|}{ Sumber Bahan Baku } \\
\cline { 2 - 3 } & $\begin{array}{c}\text { Jigana Coffee } \\
\text { Shop }\end{array}$ & Kedai Kopi Inspirasi \\
\hline 1 & $\begin{array}{c}\text { Supplier } \\
\text { (Cibinong dan } \\
\text { Bandung) }\end{array}$ & $\begin{array}{c}\text { Supplier } \\
\text { (Bogor, Wonosobo, } \\
\text { Temanggung) }\end{array}$ \\
\hline
\end{tabular}

Harga bahan baku adalah biaya yang dikeluarkan pelaku usaha atau pemilik untuk memperoleh bahan baku produknya. Jigana Coffee Shop memperoleh beans dari berbagai supplier dengan kisaran harga $\mathrm{Rp}$ 195.000 - Rp 210.000 per kilogram untuk jenis kopi robusta dan Rp 210.000 - Rp 240.000 per kilogram untuk jenis kopi arabika. Sedangkan, Kedai Kopi Inspirasi memperoleh beans dari berbagai supplier dengan kisaran harga Rp 200.000 - Rp 350.000 per kilogram untuk jenis kopi arabika dan Rp 120.000 - Rp 180.000 per kilogram untuk jenis kopi arabika.

Transportasi distribusi pengiriman bahan baku beans kopi di Jigana Coffee Shop dan Kedai Kopi Inspirasi ini dengan menggunakan fasilitas jasa pengiriman antar jemput beans kopi yang disediakan oleh supplier di daerah Cibinong dan Bogor. Sedangkan, untuk supplier yang ada di luar Cibinong dan Bogor itu menggunakan jasa ekspedisi pengiriman paket/barang online sehingga membutuhkan waktu yang lebih lama agar beans yang dipesan sampai. Adapun manajemen kualitas beans kopi dalam perjalanannya, yaitu beans kopi yang dikemas menggunakan packaging yang bagus dan tahan akan pergerakan, tidak mudah sobek dan terbuka seperi packaging air valve pouches. Setelah beans sampai, biasanya kedua kedai kopi ini men-sortir ulang beans kopi sehingga yang kualitasnya lebih bagus akan diproduksi untuk konsumen.

Pemilihan kopi nusantara sebagai jenis beans yang digunakan pada Jigana Coffee Shop dan Kedai Kopi Inspirasi yaitu karena kopi nusantara ini memiliki cita rasa dan aroma spesifik yang tentunya tidak kalah dengan kopi luar negeri. Secara umum, kualitas dari kopi nusantara baik arabika maupun robusta tergolong memiliki citarasa yang khas dan unik. Jenis kopi nusantara yang digunakan oleh Jigana Coffee Shop antara lain Aceh Gayo, Kerinci, 
Ijen Blue Mountain, dan lain-lain. Namun, Jigana Coffee Shop ini lebih sering menggunakan kopi arabika Aceh Gayo untuk memancing orang sekitar meminum kopi.

Tabel 2. Perbandingan Harga Bahan Baku Kopi di Kedai Kopi

\begin{tabular}{|c|c|c|c|}
\hline \multirow{2}{*}{ No } & \multirow{2}{*}{$\begin{array}{c}\text { Jenis } \\
\text { Kopi }\end{array}$} & \multicolumn{2}{|c|}{ Harga Bahan Baku } \\
\cline { 3 - 4 } & $\begin{array}{c}\text { Jigana } \\
\text { Coffee Shop }\end{array}$ & $\begin{array}{c}\text { Kedai Kopi } \\
\text { Inspirasi }\end{array}$ \\
\hline 1 & Arabika & $\begin{array}{c}\text { Rp } 210.000- \\
\text { Rp } 240.000\end{array}$ & $\begin{array}{c}\text { Rp } 200.000- \\
\text { Rp } 350.000\end{array}$ \\
\hline 2 & Robusta & $\begin{array}{c}\text { Rp } 195.000- \\
\operatorname{Rp} 210.000\end{array}$ & $\begin{array}{c}\text { Rp } 120.000- \\
\operatorname{Rp} 180.000\end{array}$ \\
\hline
\end{tabular}

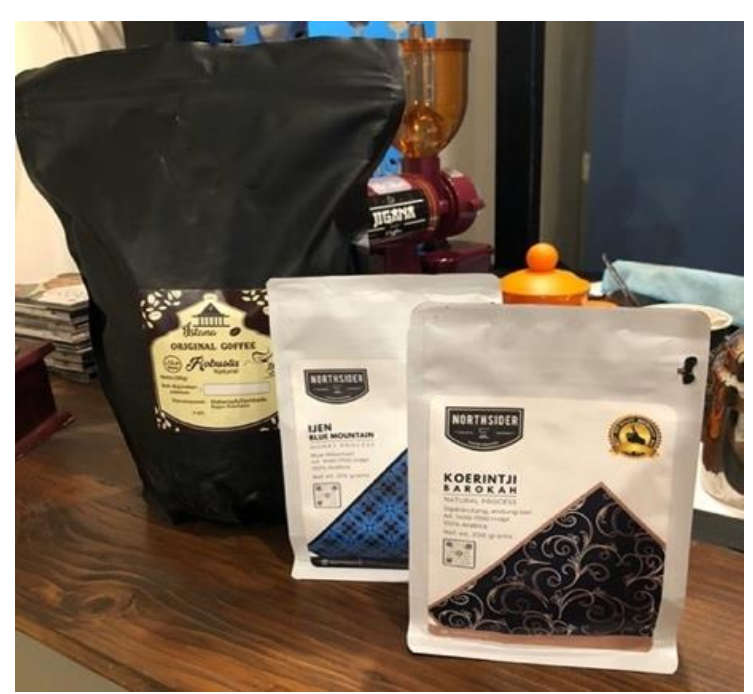

Gambar 4. Beans Kopi di Jigana Coffee Shop Sumber: Dokumentasi Pribadi (2020)

Sedangkan, jenis kopi yang digunakan Kedai Kopi Inspirasi adalah Arabika dan Robusta dengan kopi nusantara yang digunakan antara lain Java, Sindoro, Seceng, Gunung Kapencar, Aceh Gayo, dan lain-lain. Namun, Kedai Kopi Inspirasi ini lebih sering menggunakan kopi Pangalengan, Jawa Barat yaitu Malabar.

Harga kopi yang ditawarkan di Jigana Coffee Shop yaitu antara Rp 13.000 - Rp 25.000. Sedangkan, harga kopi yang ditawarkan oleh Kedai Kopi Inspirasi itu antara Rp 15.000 Rp 24.000. Harga dari kedua kedai kopi ini masih terbilang standar untuk harga original coffee yang dijual oleh kedai kopi pada umumnya.

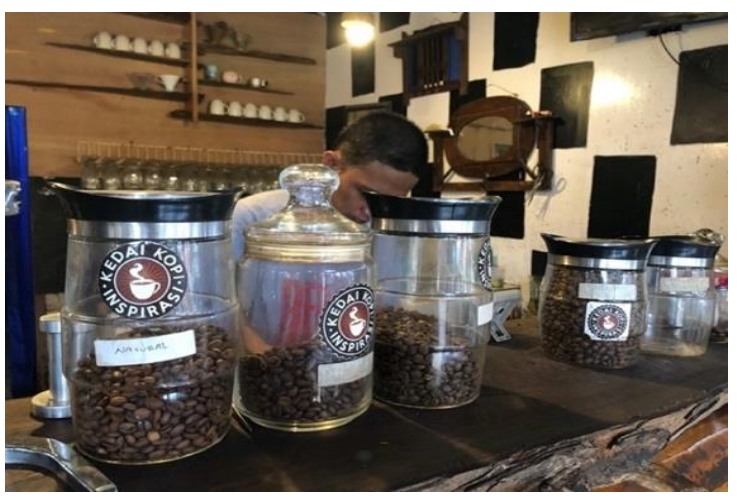

Gambar 5. Beans Kopi di Kedai Kopi Inspirasi Sumber: Dokumentasi Pribadi (2020)

Tabel 3. Perbandingan Harga Produk Kopi di Kedai Kopi

\begin{tabular}{|c|c|c|}
\hline \multirow{2}{*}{ No } & \multicolumn{2}{|c|}{ Harga Produk Kopi } \\
\cline { 2 - 3 } & Jigana Coffee & Kedai Kopi \\
& Shop & Inspirasi \\
\hline \multirow{2}{*}{1} & Rp $13.000-\operatorname{Rp}$ & Rp $15.000-$ Rp \\
& 25.000 & 24.000 \\
\hline
\end{tabular}

Selanjutnya yaitu sistem pembayaran yang ada di Jigana Coffee Shop dan Kedai Kopi Inspirasi, dimana sistem ini berkaitan dengan pemindahan uang dari alat pembayaran sederhana sampai pada penggunaan alat pembayaran dengan sistem kompleks serta melibatkan berbagai lembaga untuk ikut bekerjasama berikut aturan mainnya. Pada umumnya, sistem pembayaran yang ada di Jigana Coffee Shop dan Kedai Kopi Inspirasi itu ada 2 bentuk, yaitu cash dan $e$ money. Perbedaannya terletak pada penggunaan e-money itu sendiri, dimana Jigana Coffee Shop menggunakan alat e-money CIMB Niaga. Hal ini karena alat yang disediakan dari CIMB Niaga ini lebih praktis dan flexible dimana konsumen dapat membayar menggunakan beberapa jenis e-money lainnya, seperti Go-Pay, OVO, Dana, bank barcode, dan lainnya. Sehingga, hal tersebut dapat mempermudah konsumen dalam memilih metode pembayaran yang diinginkan. Sedangkan, Kedai Kopi Inspirasi menggunakan alat e-money dari Go-Pay dimana sistem pembayaran e-money yang dapat dilakukan oleh konsumen kedai kopi ini hanya bisa melalui aplikasi Go-Jek.

Media promosi adalah sarana mengkomunikasikan suatu produk maupun 
jasa dengan tujuan agar dapat lebih dikenal oleh masyarakat luas. Ariyanti (2014) menjelaskan bahwa tujuan utama dilakukannya promosi yaitu untuk memberikan sebuah informasi yang dapat menarik perhatian konsumen sehingga output yang diharapkan perusahaan itu dapat memberi mereka pengaruh terhadap peningkatan penjualan. Media promosi yang sudah dilakukan oleh Jigana Coffee Shop yaitu secara online melalui media sosial seperti Instagram dan juga tersedia di merchant Go-Food dan secara offline yaitu word of mouth antar keluarga dan teman.

Berbeda halnya dengan Kedai Kopi Inspirasi, dimana media promosi online yang sudah dilakukan Kedai Kopi Inspirasi seperti media sosial yang meliputi Instagram dan Facebook dengan membayar promote seharga Rp 29.000 per 3 hari untuk Instagram dan Rp 17.000 per hari selama 7 hari untuk Facebook. Sedangkan, media promosi offline yang sudah dilakukan kedai kopi ini yaitu gabung dan ikut serta ke komunitas kopi di Kabupaten Bogor, Kota Bogor, dan nasional.

Tabel 4. Perbandingan Sistem Pembayaran di Kedai Kopi

\begin{tabular}{|c|c|c|}
\hline \multirow{2}{*}{ No } & \multicolumn{2}{|c|}{ Sistem Pembayaran } \\
\cline { 2 - 3 } & $\begin{array}{c}\text { Jigana Coffee } \\
\text { Shop }\end{array}$ & $\begin{array}{c}\text { Kedai Kopi } \\
\text { Inspirasi }\end{array}$ \\
\hline 1 & Cash & Cash \\
\hline 2 & $\begin{array}{c}\text { E-money } \\
\text { (CIMB Niaga } \\
\text { Barcode) }\end{array}$ & $\begin{array}{c}\text { E-money } \\
\text { (Go-Pay) }\end{array}$ \\
\hline
\end{tabular}

Dapat disimpulkan bahwa promosi yang dilakukan oleh Kedai Kopi Inspirasi ini lebih luas dan maksimal karena pengelola kedai kopi ini adalah ketua dari Komunitas Kopi Kabupaten Bogor sehingga target pasarnya luas dan tepat. Hal ini didukung oleh pernyataan Ibnu, selaku pengunjung yang mengatakan bahwa,

"Saya mengetahui Kedai Kopi Inspirasi ini dari teman saya yang ikut gabung ke komunitas kopi Bogor, dan menurut saya tempatnya asik. Sayangnya, mungkin penggunaan media sosialnya ini kurang aktif. Jadi kalau tidak karena teman, mungkin saya tidak tau keberadaan kedai kopi ini."

Afriyanti dan Rasmikayati (2018) menjelaskan bahwa untuk meningkatkan penjualan, pihak kedai kopi sebaiknya melakukan peningkatan pada promosinya dan promosi yang dilakukan itu harus ditujukan kepada target pasar yang tepat.

\section{Potensi dan Kendala \\ Potensi.}

Jigana Coffee Shop dan Kedai Kopi Inspirasi merupakan kedai kopi yang ada di Cibinong yang menyajikan kopi nusantara berkualitas dan tersaji dalam banyak varian menu. Berdasarkan hasil survey lapangan, pendapat masing-masing konsumen mengenai kualitas produk kedua kedai kopi ini dapat dikategorikan baik. Hal ini dikarenakan sebagian besar menu yang ada ini memiliki rasa yang khas dan sesuai dengan selera konsumen. Selain itu, Kedai Kopi Inspirasi juga memiliki keunggulan lain, salah satunya produk makanan pelengkap yaitu kentang goreng dan pisang bakar yang dirasa memiliki relatif murah dengan porsi yang banyak.

Dari segi lokasi, baik Jigana Coffee Shop dan Kedai Kopi Inspirasi memiliki keunggulannya masing-masing. Jigana Coffee Shop memiliki lokasi yang cukup strategis dimana lokasi ini berada di Jalan Raya Utama yang dilalui oleh banyak kendaraan/ orang. Sedangkan, Kedai Kopi Inspirasi berlokasi di daerah yang bernuansa alam dan dikelilingin kebun jati sehingga kedai kopi ini memiliki nilai estetika yang lebih dibandingkan kedai kopi pada umumnya di Jigana Coffee Shop.

Dari segi fasilitas, Jigana Coffee Shop ini memiliki keunggulan diantaranya adanya audio musik, toilet, mushola yang luas, dan tempat parkir yang cukup luas. Sedangkan, fasilitas Kedai Kopi Inspirasi ini memiliki keunggulan seperti adanya audio musik, toilet, dan desain interior yang menarik dan unik. Hal ini didukung oleh hasil survey dengan konsumen Kedai Kopi Inspirasi dimana suasana yang ada di 
Kedai Kopi Inspirasi ini nyaman dan dilengkapi oleh desain interior yang menarik. Selain fasilitas fisik, Kedai Kopi Inspirasi ini juga menyediakan workshop mengenai kopi dan proses penyajiannya satu kali dalam setahun yang ditujukan bagi karyawan dan terbuka bagi masyarakat maupun konsumen yang ingin belajar.

Dari segi kelengkapan alat, kedua kedai kopi ini sudah memiliki perlangkapan manual brew yang cukup lengkap. Alat pelengkap lainnya yang dimiliki oleh Jigana Coffee Shop diantaranya grinder, shaker, frother, dan scale. Sedangkan, alat pelengkap lainnya yang dimiliki oleh Kedai Kopi Inspirasi diantaranya grinder, drip, scale, frother, dan jug.

Dari segi sumber daya manusia, kedua kedai kopi ini memiliki barista yang cukup handal dalam proses pembuatan minuman kopi dan ramah kepada pengunjung. Barista juga terbuka bagi pengunjung yang ingin tahu dan belajar tentang kopi dan cara pembuatan kopi itu sendiri. Hal ini didukung dengan pendapat konsumen yang mengatakan bahwa barista sangat ramah dan mau membagi ilmunya kepada mereka yang ingin tahu dan belajar lebih banyak tentang kopi.

\section{Kendala.}

Kendala yang dimiliki oleh kedua kedai kopi ini umumnya sama. Dari segi produk, yaitu jenis beans yang masih belum beragam. Hal ini dikarenakan jenis beans yang ada di kedua kedai kopi ini masih hanya ada beans yang single origin. Sedangkan, berdasarkan hasil survey dengan konsumen, sebagian dari mereka merasa bahwa jenis beans yang blend beans rasanya akan lebih enak khususnya untuk produk kopi espresso based. Selain itu, untuk Jigana Coffee Shop belum memiliki produk makanan pelengkap yang unggul karena berdasarkan pernyataan dari konsumen, harga yang ditawarkan masih relatif mahal, porsinya sedikit, dan belum memiliki rasa yang khas.

Dari segi lokasi, letak Jigana Coffee Shop ini sudah cukup strategis karena berada di pinggir jalan raya utama. Namun, kendalanya karena sejak pembukaan Jigana Coffee Shop tidak memberikan promo menarik bagi konsumen, baik berupa buy one get on atau diskon produk yang diinformasikan kepada konsumen sehingga masyarakat yang ada disekitar lokasi belum aware dengan original coffee yang harganya cenderung lebih mahal dibandingkan kopi sachet biasa. Berbeda halnya dengan Kedai Kopi Inspirasi, dimana letak kedai kopi ini kurang strategis karena berada di dalam gang perkampungan sehingga kurang memudahkan masyarakat sekitar mengetahui kedai kopi ini. Ditambah dengan tidak adanya papan nama khusus penunjuk lokasi seperti billboard atau plang di depan gang, hanya ada didepan kedai kopinya saja. Selain itu, jika musim hujan dan musim gugur tiba, hal tersebut juga menjadi salah satu kendala yang ada pada kedai kopi ini karena kedai kopi ini akan terlihat becek dan tidak rapih serta banyak sampah daun yang berguguran. Lokasi Kedai Kopi Inspirasi yang berada diperkampungan membuat kedai kopi ini tidak bisa menyetel musik sampai larut malam. Pihak kedai kopi ini memiliki komitmen dengan warga sekitar dalam hal waktu untuk penyetelan musik, yaitu sampai pukul 23.00 WIB.

Dari segi fasilitas, kedua kedai kopi ini memiliki fasilitas fisik yang cukup lengkap, namun masih terbatas untuk fasilitas yang lainnya. Tempat yang disediakan oleh Jigana Coffee Shop tidak terlalu besar dengan desain interior cenderung membosankan bagi pengunjung. Berbeda dengan Kedai Kopi Inspirasi dimana untuk fasilitas tempat parkir dirasa oleh konsumen kurang luas sehingga jika situasi di kedai kopi ini sedang ramai, konsumen cukup kesulitan untuk parkir karena penuh. Kedua kedai kopi juga belum memiliki fasilitas wifi. Padahal berdasarkan survey dengan konsumen, fasilitas tersebut merupakan fasilitas yang paling dipertimbangkan untuk mereka melakukan kunjung selain dari aspek produk dan suasana.

Dari segi kelengkapan alat, Jigana Coffee Shop hanya memiliki satu alat espresso manual, sedangkan pada Kedai 
Kopi Inspirasi hanya memiliki dua alat espresso manual. Hal tersebut menjadi kendala karena berdasarkan pendapat konsumen, apabila keadaan kedai kopi sedang ramai, mereka bisa menunggu lama sampai 30 menit.

Dari segi sumber daya manusia, Jigana Coffee Shop masih memiliki kendala dalam hal jumlah tenaga kerja dimana hanya memiliki dua tenaga kerja yang merangkap tugas sebagai pemilik, pengelola, barista, dan juru masak. Hal ini menjadi salah satu kendala kedai kopi ini pada saat pengunjung ramai, sehingga membuat para pekerja nya kewalahan dan service yang ditawarkan pun menjadi lama. Berdasarkan pendapat konsumen, service yang ada masih lama jika pengunjung ramai. Sehingga, hal tersebut juga menjadi salah satu kendala bagi Kedai Kopi Inspirasi.

\section{KESIMPULAN}

Berdasarkan hasil pembahasan dari penelitian yang telah dilakukan oleh penulis, maka dapat diambil kesimpulan sebagai berikut:

Karakteristik konsumen di Jigana Coffee Shop dan Kedai Kopi Inspirasi didominasi oleh laki-laki dan pada usia produktif, yaitu dari remaja sampai dewasa dengan penghasilan rata-rata $\mathrm{Rp} 1.000 .000$ - Rp 5.000.000. Dari segi perilaku konsumen, sebagian besar konsumen kedua kedai kopi tersebut lebih tertarik dengan kedai kopi yang rasanya enak/nikmat dan suasana yang nyaman.

Jigana Coffee Shop dengan lokasi usaha yang strategis ini masih belum memiliki strategi promosi yang dapat menarik minat konsumen untuk berkunjung. Sedangkan, Kedai Kopi Inspirasi dengan lokasi usaha yang kurang strategis ini sudah memiliki strategi promosi yang tepat sesuai dengan target pasarnya, yaitu dengan ikut gabung ke komunitas kopi Kabupaten Bogor dan menjadi ketua dari komunitas tersebut. Selain itu, desain interior dari Kedai Kopi Inspirasi ini juga berbeda dengan kedai kopi pada umumnya di Cibinong, sehingga memiliki keunikan tersendiri bagi konsumen.
Potensi Jigana Coffee Shop seperti jenis beans yang berkualitas serta barista yang ramah kepada konsumennya yang menjadi beberapa faktor konsumen datang ke kedai kopi ini meskipun penjualannya mengalami penurunan. Sedangkan, potensi Kedai Kopi Inspirasi seperti jenis beans yang berkualitas, desain interior kedai yang menarik dan unik, adanya workshop mengenai kopi yang terbuka bagi pengunjung, dan barista yang ramah ini menjadi beberapa faktor meningkatnya penjualan di kedai kopi ini. Namun, kendala Jigana Coffee Shop seperti tempat yang disediakan tidak terlalu besar dengan desain interior yang cenderung membosankan serta tidak ada wifi ini menjadi beberapa faktor menurunnya penjualan di kedai kopi ini. Sedangkan, lokasi usaha yang kurang strategis, tidak ada plang khusus penunjuk lokasi, tempat yang kurang rapih dan bersih, tidak ada wifi, dan tempat parkir yang terbatas menjadi beberapa faktor kendala yang dialami oleh Kedai Kopi Inspirasi.

\section{DAFTAR PUSTAKA}

[AEKI] Asosiasi Eksportir dan Industri Kopi Indonesia. 2016. Konsumsi Kopi Indonesia. [internet]. [7/10/19] tersedia pada http://www.aeki-aice.org/.

Afriyanti, S., \& Rasmikayati, E. (2018). Studi Strategi Pemasaran Terbaik Berdasarkan Perilaku Konsumen Dalam Menghadapi Persaingan Antar Kedai Kopi di Jatinangor. Ilmiah Mahasiswa Agroinfo Galuh, 4(3), 856872.

Amir, N. H., Rasmikayati, E., \& Saefudin, B. R. (2017). Analisis usahatani kopi di kelompok tani hutan giri senang Desa Giri Mekar Kabupaten Bandung. Jurnal ilmiah mahasiswa agroinfo galuh, 3(3), 472-479. DOI: http://dx.doi.org/10.25157/jimag.v4i3. 813.

Ariyanti T. 2014. Pengaruh strategi promosi terhadap penjualan produk di PT. United Indo Surabaya. Jurnal Ilmu \& Riset Manajemen.[Internet]. 
Anderzén, J., Guzmán Luna, A., LunaGonzález, D.V., Merrill, S.C., Caswell, M., Méndez, V.E., Hernández Jonapá, R., Mier y Terán Giménez Cacho, M., 2020. Effects of on-farm diversification strategies on smallholder coffee farmer food security and income sufficiency in Chiapas, Mexico. Journal of Rural Studies 77, 33-46.

https://doi.org/10.1016/j.jrurstud.2020. 04.001

[BPPTPM] Badan Pelayanan Perizinan Terpadu Penanaman Modal. 2014. Rekapitulasi Penerbitan Tanda Daftar Usaha Pariwisata. Bogor: BPPTPM Kota Bogor

[BPS] Badan Pusat Statistik Provinsi Jawa Barat. 2018. Jumlah Restoran atau Rumah Makan Menurut Kabupaten/Kota. [internet]. [8/10/19] tersedia pada https://jabar.bps.go.id/statictable/2018/ 03/23/472/jumlah-restoran-rumahmakan-menurut-kabupaten-kota-.html

Ballco, P., Caputo, V., de-Magistris, T., 2020. Consumer valuation of European nutritional and health claims: Do taste and attention matter? Food Quality and Preference 79, 103793. https://doi.org/10.1016/j.foodqual.2019 .103793

[FAO] Food And Agricultural Organization. 2015. Food And Agricultural Commodities Production. [7/10/19]. tersedia pada http://faostat3.fao.org/

Filimonau, V., Krivcova, M., Pettit, F., 2019. An exploratory study of managerial approaches to food waste mitigation in coffee shops. International Journal of Hospitality Management 76, 48-57. https://doi.org/10.1016/j.ijhm.2018.04. $\underline{010}$

Gerry, Y., Mongan, P., Rumagit, G. A. J., Kumaat, R. M., Sosial, J., Pertanian, E., ... Sam, U. (2019). TINGKAT KEPUASAN KONSUMEN DI RUMAH KOPI K8 DI KOTA MANADO. AGRIRUD, 1(2).
Han, H., Nguyen, H.N., Song, H., Chua, B.-L., Lee, S., Kim, W., 2018. Drivers of brand loyalty in the chain coffee shop industry. International Journal of Hospitality Management 72, 86-97. https://doi.org/10.1016/j.ijhm.2017.12. $\underline{011}$

[ICO] International Coffee Organization. Coffe Market Report May 2018.

[ICO] International Coffee Organization. Top 10 Coffee Producers 2018.

Ikhsan, Risyad Muhammad. Rasmikayati, Elly. 2016. Sikap dan Norma Subjektif Konsumen terhadap Pembelian Produk di Armor Kopi Garden (Suatu Kasus di Kedai Armor Kopi Garden, Legok Randu, Bandung). Program Studi Agribisnis. Fakultas Pertanian. Universitas Padjadjaran. Bandung.

Jeon, J.-S., Kim, H.-T., Jeong, I.-H., Hong, S.R., Oh, M.-S., Yoon, M.-H., Shim, J.H., Jeong, J.H., Abd El-Aty, A.M., 2019. Contents of chlorogenic acids and caffeine in various coffee-related products. Journal of Advanced Research 17, 85-94.

https://doi.org/10.1016/j.jare.2019.01.0 $\underline{02}$

Khan, H., Lee, R., 2020. Does packaging influence taste and quality perceptions across varying consumer demographics? Food Quality and Preference 84, 103932.

https://doi.org/10.1016/j.foodqual.2020 $\underline{.103932}$

Ni'amullah, F., Irdiana, S., \& Irawan, R. (2018). Pengaruh Store Atmosphere Terhadap Minat Beli Dan Keputusan Pembelian (Studi Kasus Pada BJ Cafe Lumajang). Riset Manajemen, 1(1), 917.

Neilson, J., Wright, J., Aklimawati, L., 2018. Geographical indications and value capture in the Indonesia coffee sector. Journal of Rural Studies 59, 35-48. https://doi.org/10.1016/j.jrurstud.2018. $\underline{01.003}$ 
Pardian, P. (2017). Persepsi dan minat petani muda dalam budidaya sayuran Swiss Chard Organik. Dharmakarya, 6(3). Diakses melalui:

http://journal.unpad.ac.id/dharmakarya /article/view/14817.

Park, S., Nam, S., Lee, J., 2017. Charitable giving, suggestion, and learning from others: Pay-What-You-Want experiments at a coffee shop. Journal of Behavioral and Experimental Economics 66, 16-22.

https://doi.org/10.1016/j.socec.2016.04 .010

Rasmikayati, E., Pardian, P., Hapsari, H., Ikhsan, R. M., \& Saefudin, B. R. (2017). Kajian Sikap dan Perilaku Konsumen dalam Pembelian Kopi serta Pendapatnya Terhadap Varian Produk dan Potensi Kedainya. Mimbar Agribisnis: Jurnal Pemikiran Masyarakat Ilmiah Berwawasan Agribisnis, 3(2), 117-133. DOI: http://dx.doi.org/10.25157/ma.v3i2.56 3.

Rasmikayati, E., Setiawan, I., \& Saefudin, B. R. (2017). Kajian Karakteristik, Perilaku dan Faktor Pendorong Petani Muda Terlibat dalam Agribisnis pada Era Pasar Global. Mimbar Agribisnis: Jurnal Pemikiran Masyarakat Ilmiah Berwawasan Agribisnis, 3(2), 134-149. DOI:

http://dx.doi.org/10.25157/ma.v3i2.56 5.

Sudjana, Nana. 2004. Dasar-dasar Proses Belajar Mengajar. Bandung : Sinar Baru Algesindo Offset.

Sukatmadiredja, N. R. (2016). Analisa Perubahan Perilaku Konsumen Terhadap Pertumbuhan Warung Kopi
Di Kecamatan Rungkut Surabaya. II(1), 340-354.

Song, H., Wang, J., Han, H., 2019. Effect of image, satisfaction, trust, love, and respect on loyalty formation for namebrand coffee shops. International Journal of Hospitality Management 79, $50-59$.

https://doi.org/10.1016/j.ijhm.2018.12. $\underline{011}$

Spiller, K., 2012. It tastes better because ... consumer understandings of UK farmers' market food. Appetite 59, 100-107.

https://doi.org/10.1016/j.appet.2012.04 .007

Tjiptono, Fandy. (2004). Strategi Pemasaran, Edisi 2. Yogyakarta: Penerbit Andi

van Ooyen-Houben, M.M.J., Bieleman, B., Korf, D.J., 2016. Tightening the Dutch coffee shop policy: Evaluation of the private club and the residence criterion. International Journal of Drug Policy 31, 113-120. https://doi.org/10.1016/j.drugpo.2016. $\underline{01.019}$

Widyotomo, S. 2013. Potensi Dan Teknologi Diversifikasi Limbah Kopi Menjadi Produk Bermutu Dan Bernilai Tambah. Review Penelitian Kopi dan Kakao. Vol. 1 (1) : 63-80.

Wang, M., Chen, L.-H., Su, P., Morrison, A.M., 2019. The right brew? An analysis of the tourism experiences in rural Taiwan's coffee estates. Tourism Management Perspectives 30, 147158. https://doi.org/10.1016/j.tmp.2019.02.0 09 